\title{
TIME AND COST INTERDEPENDENCE IN WATER SUPPLY SYSTEM CONSTRUCTION PROJECTS
}

\author{
Vahida ŽUJOa, Diana CAR-PUŠIĆb, Valentina ŽILESKA-PANČOVSKAc, \\ Marko ĆEĆEZ ${ }^{\mathrm{d}}$ \\ ${ }^{a, d}$ Faculty of Civil Engineering, "Džemal Bijedic' University of Mostar, \\ USRC "Mithad Hujdur Hujka", Mostar, Bosnia and Herzegovina \\ ${ }^{b}$ Faculty of Civil Engineering, University of Rijeka, Radmile Matejčić 3, Rijeka, Croatia \\ 'Faculty of Civil Engineering, University "Ss. Cyril and Methodius", Bld. Partizanski Odredi 24, \\ Skopje 1000, FYR Macedonia
}

Received 16 February 2013; accepted 18 January 2015

\begin{abstract}
Time and price of contracted construction as well as their overrun are among highly pronounced issues in the construction practice. Numerous studies indicate that there is a dependency between these parameters at various construction markets. The paper shows the results of a research conducted on a group of 40 projects related to water supply systems carried out in the Federation of Bosnia and Herzegovina from 2001 to 2012. Collected data, obtained through interviewing chief engineers of construction companies, have been used as input parameters for implementation of single linear regression by applying the BTC (Bromilow time-cost) algorithm. The final result is a model in the form of an exponential equation. Whereas it was obtained based on effectuated values, it can be considered appropriate for assessing and testing the construction time in the early planning stage, as well as at work contracting. Since the parameter values in the model depend on circumstances of the specific area under consideration, the application of the model is recommended primarily in the area where the research was conducted. Results of the price overrun and construction overrun interdependence have not resulted in determining the exponential model. The paper also proposes application recommendations and guidelines for further research.
\end{abstract}

Keywords: time-cost algorithm, construction price, construction time, overrun, single linear regression, model, water supply systems.

JEL Classification: L74.

\section{Introduction}

Theses about three key project indicators - cost, time and quality - are well known and accepted. However, there are numerous reasons why research often focuses on cost and time

Corresponding author Marko Ćećez

E-mail:marko.cecez@unmo.ba 
and their interdependence (Kaka, Price 1991; Flyvbjerg et al. 2002; Le-Hoai et al. 2008; Burtonshaw-Gunn 2009; Le-Hoai, Lee 2009; Car-Pušić, Radujković 2009).

Generally speaking, these parameters cannot and must not be ranked by importance. However, from a client's or a final user's point of view, these factors are not always of the same importance. Moreover, their difference is also determined by the fact that time and cost are factors which can be expressed quantitatively and unambiguously and are therefore more easy to control which is not the case with quality. Since time and cost are quantitative factors, their interdependence can be mathematically modelled. Some quality parameters are of a descriptive nature, some can be quantified, but generally an unambiguous and completely explicit determination is not possible. There is another very important difference between these factors which influences the perception of their importance. Deadline overrun and cost overrun are detected right after their occurrence and the consequences can be foreseen right away. However, quality inadequacies are not always obvious and the consequences are often detected much later. Therefore, the focal point of a research is often on time and cost of project implementation with assumption that the required quality level has been met. Introduction of quality indicators into the mathematical model whose aim is to show the cost and time correlation would significantly complicate the matters and make the practical application of the model more complex. The thesis is also supported by the assessment of model authors who have defined the model as ".... a time-cost-quality optimization model that enables managers to optimize multiobjectives. The model is from the project breakdown structure method where task resources in a construction project are divided into a series of activities and further into construction labors, materials, equipment, and administration. The resources utilized in a construction activity would eventually determine its construction time, cost, and quality, and a complex time-cost-quality trade-off model is finally generated based on correlations between construction activities." $(\mathrm{Hu}, \mathrm{He}$ 2014).

Burtonshaw-Gunn (2009) argues that “...instead of the term "quality" the term "quality profile" may be used to specify the organizational, technical and quality solutions ensuring the benefit levels expected by the end-user...” Devising a quality profile is a good method to describe the project's quality level required for the project and assigning an appropriate importance criteria weighting allows the relationship between the quality profile and the business objectives to be understood." (Burtonshaw-Gunn 2009).

The stated argument is inspiring but the real assessment can be made only after the performance valorisation of its practical application has been made. Regardless of this fact, time and cost correlation modelling along with meeting the required quality level as a prerequisite has its validity and practical application. The quality level, defined either by technical conditions or by client requirements, should be a prerequisite which must be met.

The results of numerous previously conducted studies speak in favor of the stated arguments and theses. Namely, numerous scientific studies indicate that there is a dependency between the contracted construction time and the contracted price at various construction markets. The Australian Bromilow was the first to investigate time and financial execution for a total of 329 structures in the building construction area which were built in Australia between 1963 and 1967. The research resulted in establishing the so-called "time-cost" 
model (hereinafter BTC or TC model) (Bromilow 1969). The simple linear regression analysis method was applied whose suitability was also proven in numerous later researches (Ireland 1983; Kumaraswamy, Chan 1995; Chan2001; Choudhury, Rajan 2003; Car-Pušić 2004; Car-Pušić, Radujković 2009). The significant "time-cost" model limitation is that it can be applied only in the area or country of its origin due to specific economic characteristics which are reflected on the value of model constants. Therefore, the existing models are not universally applicable and must be defined according to structure categories for each country separately. Consequently, similar studies have been conducted in many countries in order to obtain adequate and corresponding time assessment models (Kaka, Price 1991; Chan, Kumaraswamy 1995, 1999; Khosrowshahi, Kaka 1996; Chan 2001; Choudhury, Rajan 2003; Sun, Xu 2011; Durson, Stoy 2011).

The significance of cost and time relation modelling is even more prominent within the context of their frequent overrun, the fact which has been proved by numerous researches (Radujković 1997, 1999). In other words, despite the availability of various control techniques and project control software, many construction projects still do not achieve their cost and time objectives (Olawale, Sun 2010; Ahsan, Gunawan 2010).

Numerous researches have been conducted worldwide which indicate a frequent significant deadline and cost overruns of many construction projects.

So for example, in the U.S., the study of Hoffman (Hoffman et al. 2007), conducted on 332 structures constructed in the period from 2001 to 2004 , has emphasized that $72 \%$ of the structures were not completed within the satisfactory goals. $9 \%$ of the structures had a contracted construction time overrun over 2 months, and $47 \%$ over 4 months.

A similar study was conducted in Australia in the period from 1992-1999. 93 structures were analyzed, 33 of which had exceeded the deadline for more than $20 \%$, while the cost overrun was recorded in 21 structures. $35 \%$ of structures were completed within the contracted deadline and $26 \%$ of structures were constructed with the unchanged contracted price (Skitmor, Ng 2001).

According to the reports from the World Bank in 2007, road construction in India suffers about $25 \%$ of contracted price overrun and more than $50 \%$ of construction time overrun for all projects (Kenny 2010).

According to a research conducted in China (Sun, $\mathrm{Xu} 2011$ ), where only various types of reconstructed structures were considered, in 72 structures built in the period from 2006 to 2008 , the construction time overrun over $20 \%$ was recorded at $11.11 \%$ of the structures, $10-20 \%$ at $20.83 \%$ of the structures. The construction contracted price overrun of more than $10 \%$ was recorded at $26.39 \%$ of the structures and $5-10 \%$ at $55.56 \%$ of the structures.

The experience from developing and transition countries is unfortunately not better. In Slovenia, a research was conducted on a sample of 92 traffic structures built in the period from 1993 to 1998 . The obtained data showed that the average contracted time overrun was $63 \%$ and the average contracted price overrun was 51\% (Nikić 1998).

Within the scientific research project "Risk Management and Resource Management in Construction Projects" (Radujković 1999), conducted in Croatia, 333 structures were investigated in the period from 1996 to 1998. A time overrun in $78 \%$ of structures and price overrun at $81 \%$ of structures were recorded. 
The factors resulting in cost and deadline overruns have also been subject to analysis in some researches (Nikić 1998; Žujo, Car-Pušić 2009a, 2009b).

The frequency of deadline overruns, that is, an understandable general need for accurate time planning has encouraged the researchers to aim their interests at obtaining more accurate construction time results by taking a larger number of variables into consideration. Furthermore, more complex models which are based on the basic BTC model have also been developed but additional independent variables have also been introduced (number of stories, gross floor area-GFA) with cost preservation in one model (Chan, Kumaraswamy 1995). Nkado (1992) developed a more complex model based on a multiple linear regression analysis. The analysis has shown that the duration of group activities and their sequential start-start lag times can be predicted from 12 variables (e.g. gross floor area, area of ground floor, building location etc.) The costs have not been included.

Love et al. (2005) obtained interesting results based on a research conducted on 161 construction projects completed in various Australian States. By using the multiple linear regression analysis which was performed "between project duration, project type, procurement method, tender type, gross floor area (GFA) and number of stories. An alternative model to that proposed by Bromilow ... for forecasting time and cost performance is proposed. It is shown that GFA and the number of stories in a building are key determinants of time performance in projects" (Love et al. 2005). The implementation time and the GFA are of essence for cost assessment.

When more variables are introduced to possibly obtain higher result accuracy, the problem must be considered more widely. Firstly, the research results must confirm that the obtained results are indeed more accurate than those obtained by applying the basic model. Furthermore, the model complexity is regarded differently from the perspective of "mathematical complexity" compared to the perspective of application complexity in construction practice. As the experience has taught us, a relatively small increase in model complexity can result in its rejection by profession at the operative level and under conditions of its practical application, at least in post-transition business environment. Therefore, a gradual or a composite application may be a better option. In addition, there is another advantage of the cost as a predictor, which is the universality of its application regardless of the structure type. Namely, the previously determined variables "number of stories" and "floor area" are limited to application on building construction structures, that is, buildings. Thus, other characteristic variables-predictors would have to be determined for other structure types. This is, naturally, possible and even desirable in terms of improved accuracy which could be achieved and which should be confirmed by the research. However, in terms of looking for the most optimal solution which could be applied in practice, a composite application, that is, application of the TC model should be favored and a model with more variables should be applied wherever and whenever possible.

Previous analysis leads to the conclusion that there are researches which speak in favor of BTC model authenticity and credibility as well as those which dispute the model. It is a complex issue which deserves further research. It is certain that the introduction of additional variables and the application of multiple linear regression analysis complicate the matter to an extent. In the context of the previously stated thesis about the need to opti- 
mize the application of the model with one and/or more variables and especially taking into consideration the reality of aggravating economic circumstances in post-transition environment, the authors of this research have decided to analyze the BTC model as a more realistic option to be applied in the Federation of Bosnia and Herzegovina (FBiH) at the moment.

Based on previous considerations, the following main objectives of the research were defined:

1. BTC model for water supply facilities in the Federation of Bosnia and Herzegovina.

2. An analysis of the $\Delta \mathrm{C}-\Delta \mathrm{T}$ model for predicting the cost increase due to project overrun. $\Delta \mathrm{C}$ is the project price overrun and $\Delta \mathrm{T}$ is the planned project duration overrun. The main idea is to examine whether the BTC algorithm could provide an exponential model which would enable an approximative calculation of price overrun caused by the project duration overrun.

3. References and application measures as well as recommendations and guidelines for further research.

\section{Time assessment models}

Bromilow's "time-cost model" is still considered as the simplest construction time model depending on the project value. As elaborately stated in the introduction, since its creation in the 1960s it has been regularly applied and tested on different structure groups by numerous researchers. It has stood multiple tests which have proven credibility of its application on swift construction time assessment depending on the project cost. It must again be pointed out that the most significant limitation is the territory-bound application caused by differences in economic characteristics, which is reflected upon the $\mathrm{K}$ and $\mathrm{B}$ regression constant values.

The general time-cost model is:

$$
T=K \times C^{B},
$$

where: $T$ - is construction time; $C$ - is construction price; $K$ - is a constant which shows the average number of workdays for a unit monetary value (e.g. in the original Bromilow's model such value would be 1 million Australian dollars); $B$ - is a constant which shows the dependency between the time change and the project complexity expressed in cost.

The benefit of this model is its ability to undergo the following logarithmic transformation:

$$
\ln T=\ln K+B \ln C .
$$

What is thus obtained is the linear dependence function, that is, the first degree polynomial expressed as $y=a x+b$. This function points out the possibility of applying a simple regression analysis for $K$ and $B$ constant determination which is then calculated by applying the following equalities /expressions/:

$$
\begin{aligned}
& \ln K=b ; \\
& K=e^{b}
\end{aligned}
$$




$$
B=a,
$$

where: $a$ - is slope coefficient; $b$ - is interception.

For that very reason this advantage was used in the model application.

Several researchers have been making attempts to financially relate the duration of work and several other significant factors besides costs. For example, in 1994 Chan and Kumaraswany analyzed the influence of other factors on the work duration, some of which were the total gross area of the structure and the number of floors for building construction structure (Chan, Kumaraswamy 1995). It resulted in models such as:

$$
\begin{gathered}
T=L \times A^{M} ; \\
T=F \times S^{G} ; \\
T=K \times C^{B} \times A^{M},
\end{gathered}
$$

where: $L, M, F$ and $G$ - constants; $A$ - total gross area of the structure in $\mathrm{m}^{2} ; S$ - number of floors.

It is quite clear that the function dependency analysis can be continued in this direction but what has to be taken into consideration is that the increase of the number of independent variables makes the procedure more complex and requires multi-functional regression analysis application. What is important is to find a proper variable number proportion, that is, procedure complexity and the adequate result accuracy which is obtained by applying the procedure.

\section{Research in Bosnia and Herzegovina}

A similar study was conducted in the Federation of Bosnia and Herzegovina on 177 construction projects, carried out in the period from 1995 to 2006 (Žujo 2008a). For the analysis, groups of structures were formed by their type, one of which being a group of 28 water supply systems.

By interviewing the lead engineers of the contractor the data about the construction year, the contracted and the effectuated time and construction cost as well as the reasons for contracted time and price overrun were obtained. The contracted times and prices were taken from the construction contract. The deadline which was determined in writing and confirmed by the lead engineers of the contractor is considered as a date of completion. The final construction price is the result of all contracted amounts according to the basic contract and its annexes. None of the analyzed projects was arranged at a fixed price and none of the projects had the penalties paid by the contractor due to delay of works. This does not mean that paying the penalties was not contracted by any of the contracts in question. However, it was not carried out in practice. This is a quite common practice in this region. The same goes for earlier completion bonuses. For the purpose of this research, this part of the entire project is called a construction project or just a project.

By analyzing the base as a whole, the data has shown that in $51.40 \%$ of structures the contracted deadline was not met and in $41.23 \%$ of structures the contracted price was not sustained. A simultaneous overrun of both the contracted deadline and the contracted price was recorded in $27.68 \%$ of structures (Žujo 2008a). 
The main goal of the research was to determine BTC models for specific structures by regression analysis and to test their applicability in the Federation of Bosnia and Herzegovina.

The BTC models are important for a preliminary, rough planning and a swift construction time assessment in the early project stages. They must be determined for a specific region or a state because their parameter values reflect the economic circumstances and specificities. Therefore, it is not justified to apply BTC models which were determined for another region or a state.

The collected data were also used in further research for a scientific analysis confirming the authenticity of the BTC model in FBiH (Žujo, Car-Pušić 2008; Žujo 2008b; Žujo et al. 2009a, 2009b, 2009c).

The obtained data were also used to conduct research about how specific risk factors influence the contracted construction deadline overrun. Multiple linear regression analysis was applied. The research was conducted for water supply facilities (Žujo, Car-Pušić 2009b). A contribution of these researches is determination of most significant risk factors in the area which are the risk factor related to incomplete and incorrect technical documentation, as well as new technical solutions deriving from these.

Another kind of research (Žujo et al. 2010) was conducted in order to obtain and test the authenticity of the model which can be used for calculating the price increase in relation to the construction time extension, that is, the model of the following type:

$$
\Delta C=K \cdot(\Delta T)^{B}
$$

where: $\Delta C$ is the contracted price overrun; $\Delta T$ is the contracted time overrun.

A simple linear regression analysis was applied in order to analyze the linear function dependence of the price overrun and the construction time overrun for water supply systems. A very modest obtained value of determination coefficient pointed out the need for conducting further research of this dependence function.

For the purpose of this research, the 28 water supply facility construction project base, the facilities of which were constructed in the Federation of Bosnia and Herzegovina from 2004 to 2009 (Žujo, Car-Pušić 2009b), was expanded with 12 another projects constructed between 2001 and 2012 .

\section{Research methodology}

\subsection{Data base analysis}

Data were collected for a total of 40 structures in water-supply system domain.

The structures were constructed in the Federation of Bosnia and Herzegovina in the period from 2001 to 2012. Data were collected by interviewing chief engineers from construction companies of Mostar area. All examinees were asked the same questions:

- structure construction year;

- contracted construction time $T_{\mathrm{UG}}$;

- effectuated construction time $T_{\mathrm{OS}}$; 
- contracted construction price $C_{\mathrm{UG}}$;

- effectuated construction price $C_{\mathrm{OS}}$;

- reasons for disregard of contracted deadlines;

- reasons for disregard of the contracted price.

Field data with the calculation of basic statistics are presented in Table 1. The software Statistica 12 was applied. The basic statistical indicators were calculated for the entire data base. From a total of 40 structures, disregard of the contracted deadline was registered in 28 of them $(70 \%)$, while simultaneously the contracted deadline and the contracted price disregard were registered in 21 structures (52.5\%). The maximum overrun of the contracted deadline is $150 \%$ and of the price $42.62 \%$ while the average overrun of contracted deadline is $27.93 \%$ and of the price $3.90 \%$. The construction of the structure 21 in Table 1 was started but never completed and has therefore been excluded from further analysis.

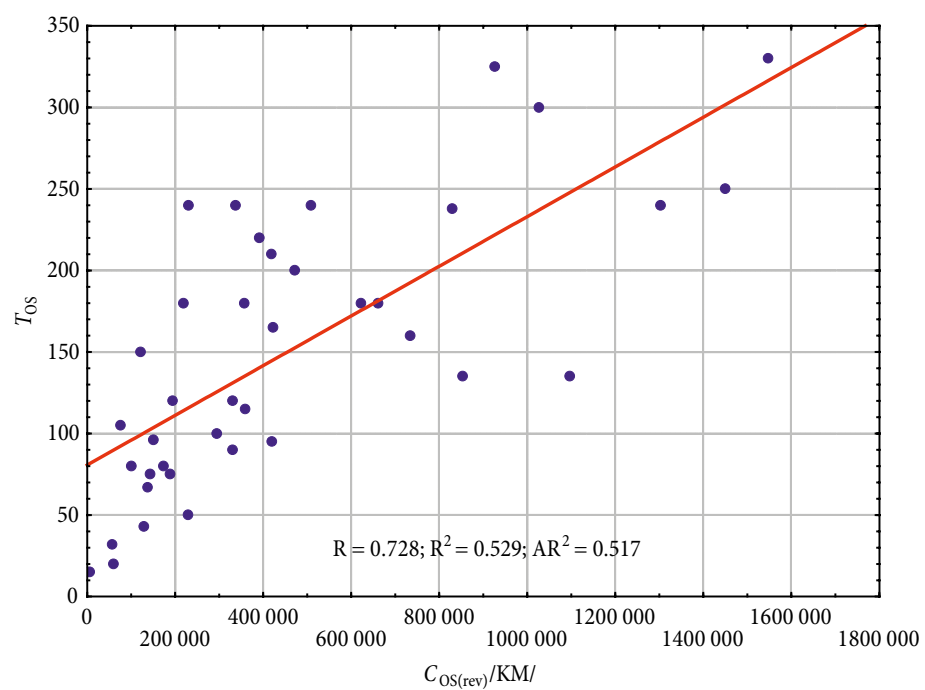

Fig. 1. Effectuated price and effectuated time ratio

Figure 1 shows relation of the effectuated price and the effectuated time. All prices have been revaluated with the price increase index compared to the same time period, i.e. November 2012, Monthly Statistical Review 2012 (Federalni zavod za statistiku 2012).

\subsection{Time-cost model for water supply facilities}

The goal is to determine and test the model based on 39 water supply facilities which enables a swift construction time assessment and is based on the BTC model.

\subsubsection{Model algorithm}

The algorithm which is presented hereinafter is basically based on a multiply tested basic BTC model algorithm and simple regression analysis application patterns. 
Table 1. Database with basic statistical indicators

\begin{tabular}{|c|c|c|c|c|c|c|c|c|c|}
\hline \multirow[t]{2}{*}{ Struct. } & \multirow{2}{*}{$\begin{array}{l}\text { Const. } \\
\text { year }\end{array}$} & \multicolumn{3}{|c|}{$\begin{array}{l}\text { Construction } \\
\text { time [days] }\end{array}$} & \multicolumn{3}{|c|}{$\begin{array}{l}\text { Revaluated construction price } \\
\qquad[\mathrm{KM}]^{1}\end{array}$} & \multicolumn{2}{|c|}{$\begin{array}{l}\text { Overruns } \\
{[\%]}\end{array}$} \\
\hline & & $T_{\mathrm{UG}}$ & $T_{\mathrm{OS}}$ & $\Delta T^{2}$ & $C_{\mathrm{UG}(\mathrm{rev})}$ & $C_{\mathrm{OS} \text { (rev) }}$ & $\Delta C^{3}$ & $T$ & $\Delta C$ \\
\hline 1 & 2002 & 120 & 238 & 118 & 710425.42 & 830732.50 & 120307.08 & 98.33 & 16.93 \\
\hline 2 & 2001 & 90 & 210 & 120 & 438535.83 & 419661.69 & -18874.14 & 133.33 & -4.30 \\
\hline 3 & 2002 & 240 & 330 & 90 & 1514408.08 & 1548558.92 & 34150.84 & 37.50 & 2.26 \\
\hline 4 & 2002 & 15 & 15 & 0 & 7206.06 & 7206.06 & 0.00 & 0.00 & 0.00 \\
\hline 5 & 2002 & 60 & 80 & 20 & 98098.17 & 101431.50 & 3333.33 & 33.33 & 3.40 \\
\hline 6 & 2003 & 90 & 105 & 15 & 74243.61 & 76939.26 & 2695.65 & 16.67 & 3.63 \\
\hline 7 & 2003 & 90 & 100 & 10 & 294453.90 & 296175.63 & 1721.73 & 11.11 & 0.58 \\
\hline 8 & 2003 & 60 & 80 & 20 & 170458.26 & 174371.30 & 3913.04 & 33.33 & 2.30 \\
\hline 9 & 2004 & 225 & 300 & 75 & 1012933.17 & 1027941.35 & 15008.18 & 33.33 & 1.48 \\
\hline 10 & 2004 & 220 & 220 & 0 & 366686.29 & 392140.50 & 25454.21 & 0.00 & 6.94 \\
\hline 11 & 2004 & 180 & 180 & 0 & 616970.99 & 661661.49 & 44690.50 & 0.00 & 7.24 \\
\hline 12 & 2004 & 96 & 96 & 0 & 145634.83 & 151728.73 & 6093.90 & 0.00 & 4.18 \\
\hline 13 & 2004 & 145 & 325 & 180 & 927085.40 & 927085.42 & 0.02 & 124.14 & 0.00 \\
\hline 14 & 2005 & 20 & 20 & 0 & 60741.29 & 60741.29 & 0.00 & 0.00 & 0.00 \\
\hline 15 & 2005 & 60 & 150 & 90 & 86198.17 & 122935.78 & 36737.61 & 150.00 & 42.62 \\
\hline 16 & 2005 & 225 & 240 & 15 & 1490197.25 & 1303869.72 & -186327.53 & 6.67 & -12.50 \\
\hline 17 & 2005 & 225 & 240 & 15 & 557135.46 & 510010.46 & -47125.00 & 6.67 & -8.46 \\
\hline 18 & 2005 & 60 & 67 & 7 & 138461.61 & 138461.61 & 0.00 & 11.67 & 0.00 \\
\hline 19 & 2006 & 60 & 75 & 15 & 189938.20 & 189938.20 & 0.00 & 25.00 & 0.00 \\
\hline 20 & 2004 & 90 & 90 & 0 & 322667.27 & 331693.82 & 9026.55 & 0.00 & 2.80 \\
\hline 21 & 2005 & 180 & $?^{4}$ & $?$ & 431917.00 & 503904.55 & 71987.55 & $?$ & 16.67 \\
\hline 22 & 2005 & 60 & 120 & 60 & 183641.82 & 195568.42 & 11926.60 & 100.00 & 6.49 \\
\hline 23 & 2005 & 180 & 200 & 20 & 446738.32 & 472958.72 & 26220.40 & 11.11 & 5.87 \\
\hline 24 & 2004 & 180 & 180 & 0 & 361674.61 & 358386.67 & -3287.94 & 0.00 & -0.91 \\
\hline 25 & 2005 & 180 & 240 & 60 & 324545.45 & 338749.54 & 14204.09 & 33.33 & 4.38 \\
\hline 26 & 2005 & 180 & 180 & 0 & 220183.49 & 220183.49 & 0.00 & 0.00 & 0.00 \\
\hline 27 & 2005 & 180 & 240 & 60 & 218807.34 & 230842.20 & 12034.86 & 33.33 & 5.50 \\
\hline 28 & 2005 & 180 & 180 & 0 & 623442.18 & 623442.18 & 0.00 & 0.00 & 0.00 \\
\hline 29 & 2007 & 150 & 165 & 15 & 396559.83 & 423066.35 & 26506.52 & 10.00 & 6.68 \\
\hline 30 & 2008 & 90 & 120 & 30 & 320592.23 & 332045.45 & 11453.22 & 33.33 & 3.57 \\
\hline 31 & 2008 & 95 & 95 & 0 & 420647.57 & 420647.57 & 0.00 & 0.00 & 0.00 \\
\hline 32 & 2008 & 115 & 135 & 20 & 805345.96 & 854577.13 & 49231.17 & 17.39 & 6.11 \\
\hline 33 & 2009 & 30 & 32 & 2 & 54749.76 & 57877.95 & 3128.19 & 6.67 & 5.71 \\
\hline 34 & 2009 & 210 & 250 & 40 & 1397852.39 & 1451024.72 & $53 \quad 172.33$ & 19.05 & 3.80 \\
\hline 35 & 2010 & 50 & 50 & 0 & 230000.00 & 230000.00 & 0.00 & 0.00 & 0.00 \\
\hline 36 & 2010 & 100 & 135 & 35 & 981340.34 & 1097102.77 & 115762.43 & 35.00 & 11.80 \\
\hline 37 & 2011 & 60 & 75 & 15 & 144290.76 & 144290.76 & 0.00 & 25.00 & 0.00 \\
\hline 38 & 2011 & 120 & 160 & 40 & 661509.23 & 735280.99 & $73.771,76$ & 33.33 & 11.15 \\
\hline 39 & 2011 & 100 & 115 & 15 & 344307.00 & 360219.00 & 15912.00 & 15.00 & 4.62 \\
\hline \multirow[t]{10}{*}{40} & 2012 & 45 & 43 & -2 & 129547.55 & 129547.55 & 0.00 & -4.44 & 0.00 \\
\hline & & & & & & Average & & 27.93 & 3.69 \\
\hline & & & & & & Median & & 15.00 & 2.80 \\
\hline & & & & & & Minimum & & -4.44 & -12.50 \\
\hline & & & & & & Maximum & & 150.00 & 42.62 \\
\hline & & & & & & The first quart & & 0.00 & 0 \\
\hline & & & & & & The third quar & & 33.33 & 5.79 \\
\hline & & & & & & Interquartile $\mathrm{c}$ & eviation & 33.33 & 4.67 \\
\hline & & & & & & Standard devi & tion & 39.20 & 8.17 \\
\hline & & & & & & Variance & & 1536.84 & 66.74 \\
\hline
\end{tabular}

Notes: ${ }^{1}$ convertiblke mark (FBiH currency, $1 \mathrm{KM} 0.5 €$ ); ${ }^{2}$ contracted time overrun, $\Delta T=T_{\mathrm{OS}}-T_{\mathrm{UG}}$; ${ }^{3}$ re-evaluated contracted price overrun, $\Delta C=C_{\mathrm{OS}}(\mathrm{rev})-C_{\mathrm{UG}}(\mathrm{rev}) ;{ }^{4}$ The construction of the structure was never completed. 
A single regression analysis represents a mathematical equation that expresses a single random variable correlatively related with another random variable. It is among the oldest statistical methods applied in research of various scientific fields.

The function is a first degree polynomial $y=a x+b$ and is called the regression straight line (Johnson, Bhattacharyya 2001; Pauše 1993; Pavlić 1988). The application of a single linear regression on the research is conducted in the following steps:

- revalue the price with price increase index compared to the same time period, i.e. November 2012 (Monthly Statistical Review 2012);

- calculate the natural logarithms $\ln T_{\mathrm{os}}$ and $\ln C_{\mathrm{os}}$ for the obtained field data;

- determine the correlation coefficients $\mathrm{R}$, determination coefficient $\mathrm{R}^{2}$, adjusted determination coefficient $\mathrm{AR}^{2}$ and standard error assessment as basic indicators of research result relevance;

- examine the linear dependence between the variables $T-C$ using the correlation draw the "estimated value-residuals" diagram in order to additionally verify the results. Scattered points in the diagram point out random errors;

- if the model can be assessed as the adequate one, the assessment indicators for the gradient and the section as well as the maximum and minimum values of $95 \%$ confidence interval are adopted. The parameter values of the models $\mathrm{K}$ and $\mathrm{B}$ are calculated with adequate formulas/expressions (3).

For the calculation of statistical indicators and conducting of the single regression analysis the software Statistica v.12. was used.

As already noted, the first step was to make a price revaluation with price increase index compared to the same time period, i.e. November 2012 (Monthly Statistical Review 2012).

Since the projects were carried out during a longer period of time, from 2002 until 2012, a price re-evaluation must be made with an adequate price increase index. All project prices must be re-evaluated to the same date, month and year. Here, the re-evaluation was made for November 2012. The price increase index was taken from the Monthly statistical overview of Federal Statistics Institute in the Federation of Bosnia and Herzegovina. Since all the projects were carried out in the Federation of Bosnia and Herzegovina, this was the only justifiable option for price increase index. Moreover, as previously mentioned, due to the economic characteristics expressed by the obtained $\mathrm{K}$ and $\mathrm{B}$ parameters, the obtained model is justifiable only for the area where the research has been conducted. Since the price increase index also expresses the economic characteristics of the area, only the option of selecting the stated price increase index is justifiable in this case. The offered explanation corresponds to the explanation of the Bromilow model (Bromilow 1969; Bromilow et al. 1980; Kaka, Price 1991).

By applying the described algorithm on a base of 39 structures with effectuated time and cost values (Fig. 1) input data for a simple linear regression analysis shown in Table 2 are obtained. The regression indicators are shown in Table 3. The values $\mathrm{AR}^{2}$ and probability $\mathrm{p}$ justify the adoption of linear regression dependency between variables. 
Table 2. Input data for linear regression

\begin{tabular}{|c|c|c|c|c|c|c|c|}
\hline $\begin{array}{l}\text { Structure/ } \\
\text { case }\end{array}$ & $T_{\mathrm{os}}$ & $C_{\mathrm{os}}$ & $C_{\mathrm{os}(\mathrm{rev})}{ }^{\star} 10^{(-5)}$ & $\ln T_{\text {os }}$ & $\begin{array}{c}\ln \left(C_{\text {os (rev) }}\right) \\
\left.{ }^{*} 10^{(-5)}\right)\end{array}$ & $\ln \Delta T$ & $\begin{array}{c}\ln \left(\Delta C_{\mathrm{rev}}\right. \\
\left.{ }^{\star} 10^{(-5)}\right)\end{array}$ \\
\hline $1 / 1$ & 238 & 996879.00 & 8.30733 & 5.4723 & 2.11714 & 4.7707 & 0.18488 \\
\hline $2 / 2$ & 210 & 503594.03 & 4.19662 & 5.3471 & 1.43428 & 4.7875 & \\
\hline $3 / 3$ & 330 & 1858270.70 & 15.48559 & 5.7991 & 2.73991 & 4.4998 & -1.07438 \\
\hline $4 / 4$ & 15 & 8647.27 & 0.07206 & 2.7081 & 2.63025 & & \\
\hline $5 / 5$ & 80 & 121717.80 & 1.01432 & 4.3820 & 0.01421 & 2.9957 & -3.40120 \\
\hline $6 / 6$ & 105 & 88480.15 & 0.76939 & 4.6540 & 0.26215 & 2.7081 & -3.61353 \\
\hline $7 / 7$ & 100 & 340601.98 & 2.96176 & 4.6052 & 1.08578 & 2.3026 & -4.06184 \\
\hline $8 / 8$ & 80 & 200527.00 & 1.74371 & 4.3820 & 0.55602 & 2.9957 & -3.24085 \\
\hline $9 / 9$ & 300 & 1130735.49 & 10.27941 & 5.7038 & 2.33014 & 4.3175 & -1.89657 \\
\hline $10 / 10$ & 220 & 431354.55 & 3.92141 & 5.3936 & 1.36645 & & -1.36829 \\
\hline $11 / 11$ & 180 & 727827.64 & 6.61661 & 5.1930 & 1.88958 & & -0.80541 \\
\hline $12 / 12$ & 96 & 166901.60 & 1.51729 & 4.5643 & 0.41692 & & -2.79788 \\
\hline $13 / 13$ & 325 & 1019793.94 & 9.27085 & 5.7838 & 2.22688 & 5.1930 & \\
\hline $14 / 14$ & 20 & 66208.01 & 0.60741 & 2.9957 & 0.49855 & & \\
\hline $15 / 15$ & 150 & 134000.00 & 1.22936 & 5.0106 & 0.20649 & 4.4998 & -1.00137 \\
\hline $16 / 16$ & 240 & 1421218.00 & 13.03870 & 5.4806 & 2.56792 & 2.7081 & \\
\hline $17 / 17$ & 240 & 555911.40 & 5.10010 & 5.4806 & 1.62926 & 2.7081 & \\
\hline $18 / 18$ & 67 & 150923.15 & 1.38462 & 4.2047 & 0.32542 & 1.9459 & \\
\hline $19 / 19$ & 75 & 199435.11 & 1.89938 & 4.3175 & 0.64153 & 2.7081 & \\
\hline $20 / 20$ & 90 & 364863.20 & 3.31694 & 4.4998 & 1.19904 & & -2.40500 \\
\hline $22 / 21$ & 120 & 213169.58 & 1.95568 & 4.7875 & 0.67074 & 4.0943 & -2.12640 \\
\hline $23 / 22$ & 200 & 515525.00 & 4.72959 & 5.2983 & 1.55384 & 2.9957 & -1.33863 \\
\hline $24 / 23$ & 180 & 394225.33 & 3.58387 & 5.1930 & 1.27644 & & \\
\hline $25 / 24$ & 240 & 369237.00 & 3.38750 & 5.4806 & 1.22009 & 4.0943 & -2.19602 \\
\hline $26 / 25$ & 180 & 240000.00 & 2.20183 & 5.1930 & 0.78929 & & \\
\hline $27 / 26$ & 240 & 251618.00 & 2.30842 & 5.4806 & 0.83656 & 4.0943 & -2.11736 \\
\hline $28 / 27$ & 180 & 679551.98 & 6.23442 & 5.1930 & 1.83009 & & \\
\hline $29 / 28$ & 165 & 439989.00 & 4.23066 & 5.1059 & 1.44236 & 2.7081 & -2.64510 \\
\hline $30 / 29$ & 120 & 342006.81 & 3.32045 & 4.7875 & 1.20010 & 3.4012 & -2.16690 \\
\hline $31 / 30$ & 95 & 433267.00 & 4.20648 & 4.7875 & 1.43663 & & \\
\hline $32 / 31$ & 135 & 880214.44 & 8.54577 & 4.9053 & 2.14544 & 2.9957 & -0.70864 \\
\hline $33 / 32$ & 32 & 59324.90 & 0.57878 & 3.4657 & 0.54683 & 0.6931 & -3.42918 \\
\hline $34 / 33$ & 250 & 1487300.34 & 14.51025 & 5.5215 & 2.67486 & 3.6889 & -0.57966 \\
\hline $35 / 34$ & 50 & 230000.00 & 2.30000 & 3.9120 & 0.83291 & & \\
\hline $36 / 35$ & 135 & 1097102.77 & 10.97103 & 4.9053 & 2.39526 & 3.5553 & 0.14637 \\
\hline $37 / 36$ & 75 & 144290.76 & 1.44291 & 4.3175 & 0.36666 & 2.7081 & \\
\hline $38 / 37$ & 160 & 735280.99 & 7.35281 & 5.0752 & 1.99508 & 3.6889 & -0.30419 \\
\hline $39 / 38$ & 115 & 360219.00 & 3.60219 & 4.7449 & 1.28154 & 2.7081 & -1.83810 \\
\hline $40 / 39$ & 43 & 129547.55 & 1.29548 & 3.7612 & 0.25888 & & \\
\hline
\end{tabular}


Table 3. Regression Results for dependent variable $\ln T_{\mathrm{os}}$

\begin{tabular}{lcccccc}
\hline \multirow{2}{*}{$\mathrm{N}=39$} & \multicolumn{6}{c}{$\mathrm{R}=0.830 ; \mathrm{R}^{2}=0.680 ; \mathrm{AR}^{2}=0.668 ; \mathrm{F}(1.37)=81.881 ; \mathrm{p}<0,000 ;$ Std. Error $=0.411$} \\
\cline { 2 - 7 } & $\mathrm{b}^{*}$ & Std.Err. of $\mathrm{b}^{*}$ & $\mathrm{~B}$ & Std.Err. of $\mathrm{b}$ & $\mathrm{t}(37)$ & $\mathrm{p}$-value \\
\hline Intercept & & & 4.187 & 0.095 & 43.909 & 0.000 \\
\hline $\ln C_{\text {os(rev })}$ & 0.830 & 0.092 & 0.566 & 0.063 & 9.049 & 0.000 \\
\hline
\end{tabular}

The obtained correlation coefficients $\mathrm{R}=0.830$ and determination coefficients $\mathrm{R}^{2}=$ 0.680 are within the satisfying limits as well as the adjusted determination coefficient $\mathrm{AR}^{2}=$ 0.668. Also, testing of the zero hypotheses has confirmed the assumption that the time of the structure is in the function of price of that structure. In other words, the test value $F$ and $t$, as well as values of the empirical significance value indicate that described independent variable $C$ has a significant impact on the dependent variable $T$. The graphic presentation shown in Figure 2 proves that the line describes the dependency of the variables in a satisfactory manner.

By applying the adequate equations the $\mathrm{K}$ and $\mathrm{B}$ constant values are obtained.

$$
\begin{gathered}
\ln T_{o s}=4.187+0.566 \ln C_{o s(r e v)} ; \\
T=66 \times C^{0.566} .
\end{gathered}
$$

The obtained model can be applied for swift assessment of water supply structure construction time in the Federation of Bosnia and Herzegovina. The obtained K and B parameter values do not significantly vary from those obtained by a previous research (Žujo 2008a).

Diagrammatic presentation of $\ln T_{\mathrm{os}}-\ln C_{\mathrm{os}}$ relationdoes not rule out the possibility of approximating a linear function. However, the $\mathrm{AR}^{2}$ coefficient value indicate the necessity of further analysis. The coefficient values are low but do not exclude the linear approximation possibility. The lower $\mathrm{AR}^{2}$ value for contracted time and cost values points to larger

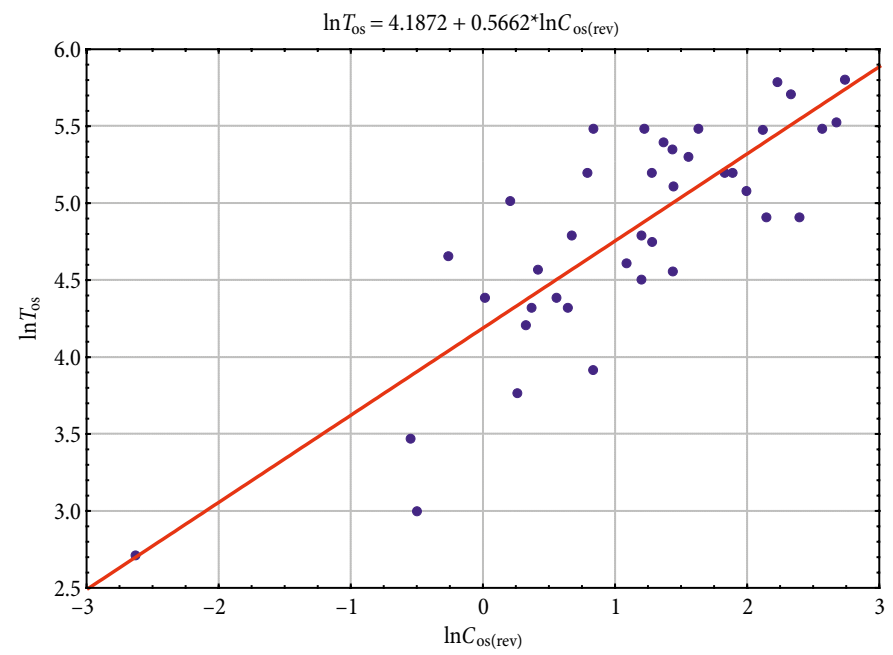

Fig. 2. Regression function $\ln T_{\text {os }}-\ln C_{\text {os(rev })}$ 
deviations from "averaged" values. Partly, they are the result of different circumstances at time of contracting, that is, the absence of real construction time and price planning. Since the effectuated values are actually more important than the contracted ones because they reflect the actual abilites of performance, they should be taken as guidelines when contracting. Further analyses will be conducted based on 39 structures with effectuated time and cost values.

The examination of values on the "assessed values - residuals" graphic presentation in Figure 3 points out a random arrangement of dots, which is an additional result verification. Table 4 shows statistical indicators of residual values.

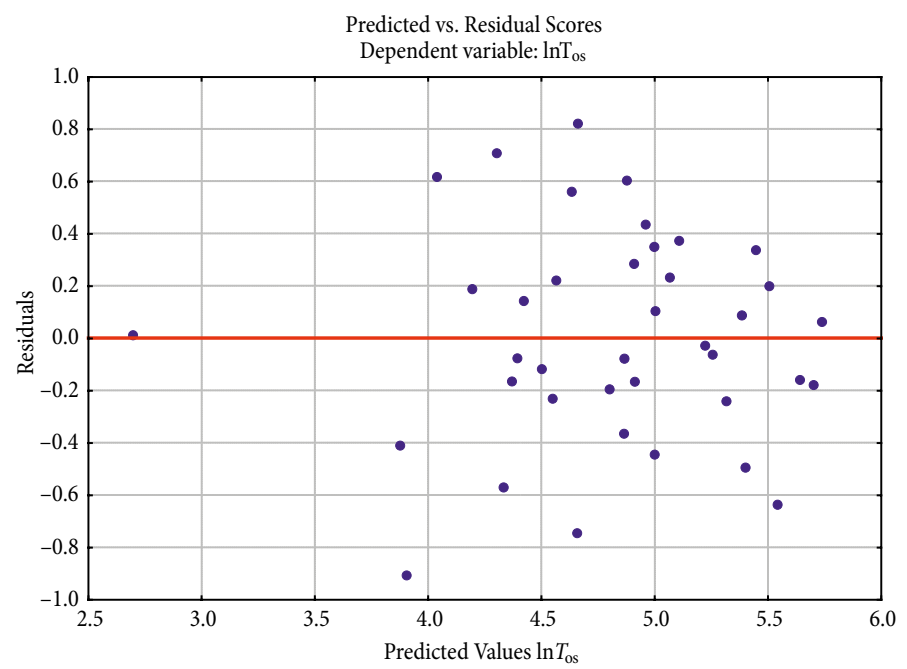

Fig. 3. Graphic presentation of the "assessed value - residuals"

Table 4. Statistical indicators of residual values

\begin{tabular}{lcccccc}
\hline \multicolumn{1}{c}{ Value } & $\begin{array}{c}\text { Observed } \\
\text { value }\end{array}$ & $\begin{array}{c}\text { Predicted } \\
\text { value }\end{array}$ & Residual & $\begin{array}{c}\text { Standard } \\
\text { pred. value }\end{array}$ & $\begin{array}{c}\text { Standard } \\
\text { residual }\end{array}$ & $\begin{array}{c}\text { Std. err. } \\
\text { pred. v. }\end{array}$ \\
\hline Minimum & 2.708050 & 2.697874 & -0.909204 & -3.50449 & -2.21254 & 0.065811 \\
\hline Maximum & 5.799093 & 5.738693 & 0.819704 & 1.53664 & 1.99474 & 0.242707 \\
\hline Mean & 4.811788 & 4.811788 & 0.000000 & -0.00000 & 0.00000 & 0.087841 \\
\hline Median & 4.905275 & 4.878105 & -0.030554 & 0.10994 & -0.07435 & 0.080002 \\
\hline
\end{tabular}

The credibility of applying the BTC algorithm on water supply system facilities in the Federation of Bosnia and Herzegovina has thus been confirmed. The main goal and purpose of the BTC model is to use time and price values obtained for a specific area or country as a base for establishing a model which would enable a swift assessment of construction time in early planning stages. This was made here, too. The regression analysis was conducted on effectuated construction time and cost values, on a relatively large specimen of structures which were under construction for a longer period of time. Since the struc- 
tures in question are relatively simple, almost typical structures without many finishing works, it can be concluded that the obtained model meets the requirements for a swift and simple construction time assessment of structures of similar nature.

\subsubsection{Correlation between time and cost overruns}

The main goal of this part of the research was to examine the suitability of applying the BTC algorithm for determining the swift approximate project price overrun increase caused by the expected overrun of its duration. If the obtained regression indicators were acceptable, an exponential model could be established and applied for a swift assessment of water facility price overrun due to project duration overrun. As previously stated, the analyzed base does not include contracts with fixed price or price increase or decrease caused by calculated penalties or bonuses. That means that the price overrun caused by real costs, which are the result of construction works and accompanying costs, could be calculated by applying the exponential model.

However, a closer inspection of the scatter diagram (Fig. 4) points to examining the possibility of linear approximation. Upon analyzing the data shown in Table 2, deadline and price overruns appear with some of the structures, deadline overrun appears with another part of the structures, and price overruns with some other structures, while deadline overrun and a reduced price appear with several structures. This reduction in price is the result of a certain haphazardness and inconsistency in establishing the price growth index which was present in the Federation of Bosnia and Herzegovina at that time.

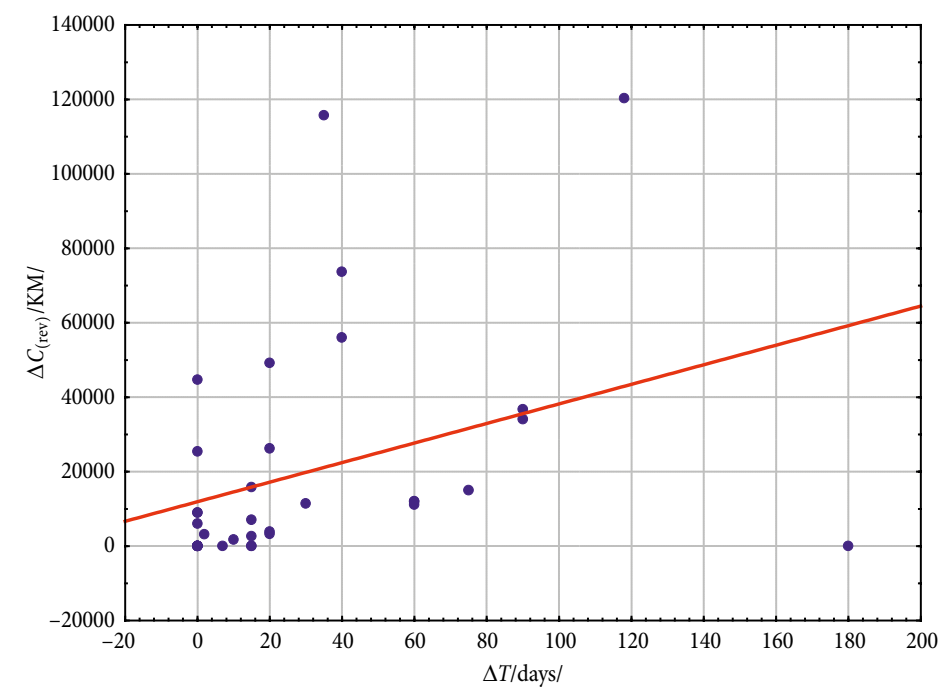

Fig. 4. Time and cost overruns

Taking all circumstances into consideration, the analysis was made for a data base which includes 28 structures with previously determined deadline and/or cost overruns.

The BTC model was taken as the starting point for the hypothetic model. Therefore, the hypothetic model is in the form of an exponential equation: 


$$
\Delta C=K \cdot(\Delta T)^{B}
$$

where: $\Delta C$ is contracted construction price overrun; $\Delta T$ is planned time ${ }^{1}$ overrun due to risk effects [days]; $K$ is model parameter indicating the required average overrun of the contracted price for a specified time period ${ }^{2} ; B$ is model parameter showing the dependence of changes in cost overruns on the change of time overrun.

$$
\ln \Delta C=\ln K+B \cdot \ln \Delta T,
$$

where: $\Delta T$ is the contracted construction time overrun, that is, the difference between the contracted and effectuated time [days]; $\Delta C$ is the contracted construction price overrun, that is, the difference between the contracted and effectuated price, revalued with $\mathrm{XI} / 12$ $[\mathrm{KM}] ; \ln \Delta T$ is the natural logarithm for the contracted time overrun; $\ln \Delta C$ is the natural logarithm for the contracted price, re-evaluated price overrun.

The linear form enables application of a single linear regression which determines values of the parameters $K$ and $B$. Obtaining of the $K$ and $B$ parameters which are entered into the basic exponential model is the primary purpose of the linear regression analysis.

The natural logarithms of the contracted price overrun and contracted time overrun were calculated $(\ln \Delta T$ and $\ln \Delta C)$ and input data for the single regression analysis were thus obtained. The necessity of undertaking this step results from the basic BTC model algorithm. Input data for regression are shown in Table 2.

However, as shown in Table 5, the obtained regression indicators are very poor $\left(\mathrm{AR}^{2}=\right.$ 0.017 ) and do not justify the regression analyses application at all, which is also well confirmed by the scatter diagram value graphic presentation in Figure 5. Therefore, it cannot be stated that the prolonged construction time over a defined time period, e.g. work day) will result in value $K$ price increase - the calculated parameter in the equation. Nevertheless, prior research (Žujo et al. 2010) suggest an additional issue deliberation. The result may lie within a numerously larger and more homogenous data base (e.g. according to structure value) for which a satisfactory result would be obtained. Such result would enable an approximate assessment of cost rise due to constructon time overrun.

The results obtained from this research and previous researches (Žujo et al. 2010) as well as the requirements of the practice point to the advisability of further research.

Table 5. Results of a single regression

\begin{tabular}{ccccc}
\hline $\mathrm{R}$ & $\mathrm{R} 2$ & $\mathrm{AR} 2$ & $\mathrm{~F}$ & $\mathrm{P}$ \\
\hline 0.256392 & 0.065737 & 0.016565 & 1.336874 & $<0.261918$ \\
\hline
\end{tabular}

\footnotetext{
1 Construction time determined by the "time-cost" model.

2 For example, one day.
} 


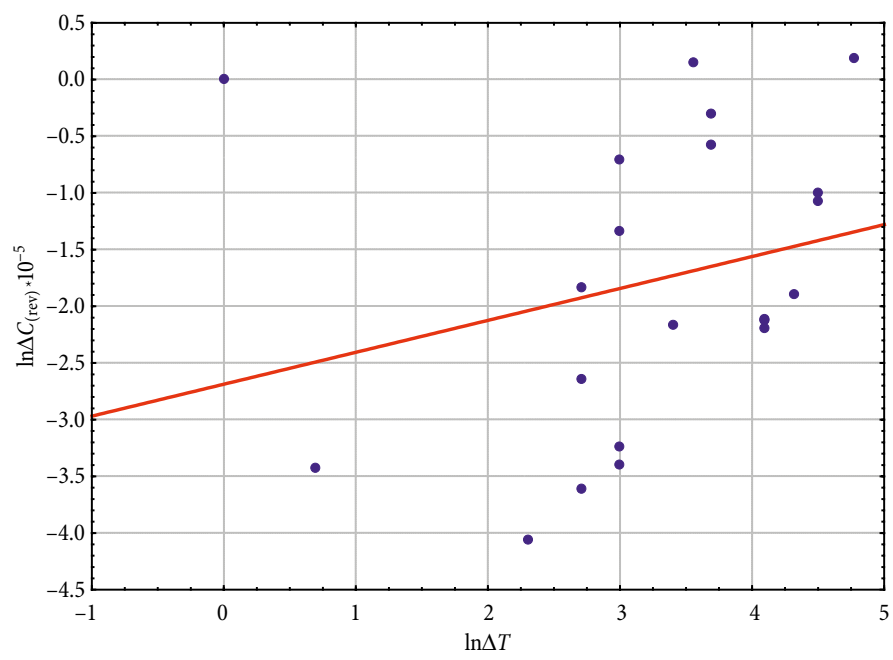

Fig. 5. Scatter diagram of $\ln \Delta C_{(\mathrm{rev})}{ }^{\star} 10^{-5}-\ln \Delta T_{\mathrm{os}}$

\subsubsection{Application measures, recommendations and guidelines for further research}

Measures, recommendations and guidelines are pertained to determination of appropriate models for construction time assessment and project price overrun. The main goal is to obtain relatively simple and practice-adequate models which enable a swift approximate calculation of these values.

Possible guidelines for further research are:

1. Modeling on larger and more homogenous bases (e.g. according to the project value, structure type and other);

2. Enlargement of the base with additional variables related to the technical characteristics of the structure (e.g. structure surface, number of water facility chambers and other technical data);

3. Enlargement of the base with additional variables related to risks causing the project time overrun;

4. Application of multidimensional regression analysis by introducing new variables

5. Application of non-linear models.

A creation of a historical and contemporary data base with special reference to similar projects is recommended. Such approach enables creation of homogenous bases as bases for modeling.

It must be taken into consideration that the introduction of new variables contributes to the accuracy of the parameters but complicates the calculation at the same time. Therefore, an optimal solution is to be sought. 


\section{Conclusions}

By applying the BTC algorithm a model for swift time assessment of water supply structure construction was obtained. The regression analysis was conducted on effectuated construction time and cost values, on a relatively large specimen of structures which were under construction for a longer period of time. Since the structures in question are relatively simple, almost typical structures without many finishing works, it can be concluded that the obtained model meets the requirements for a swift and simple construction time assessment of structures of similar nature. By testing the zero-hypothesis the credibility of the BTC model was reconfirmed.

According to the obtained information, no similar research characterized by the stated approach and goals has been conducted in these regions. In order to apply the methodology in a specific geographical area with specific economic characteristics, the research is to be conducted because it enables determination of parameters required for time and cost estimation models.

Results of analyzing the interdependence of project price overrun and duration overrun by applying the BTC algorithm have not provided results which could enable determination of an acceptable exponential mode. The results of this research and of the previous ones (Žujo et al. 2010) as well as requirements which resulted from practice point to the advisability of further research. It should be directed towards introducing new variables (technical characteristics of the structure and risks) and applying a multi-variant linear regression analysis as well as non-linear models.

Better results are obtained by modeling on larger and more homogenous bases. Bearing that in mind a special attention is paid to the possibility and requirements needed for creating a historical and contemporary data base with special reference to similar projects. What is proposed is a categorization of structures according to technical characteristics, contract awards, types of contracts, contracted price intervals, etc., that is, the most possible homogenization of each structure group. Any data base homogenization contributes to the higher accuracy of model parameters.

\section{References}

Ahsan, K.; Gunawan, I. 2010. Analysis of cost and schedule performance of international development projects, International Journal of Project Managemet 28(1): 68-78. http://dx.doi.org/10.1016/j.ijproman.2009.03.005

Burtonshaw-Gunn, S. A. 2009. Risk and financial management in construction. Farnham: Gower Publishing Ltd.

Bromilow, F. J. 1969. Contract time performance expectations and the reality, Building Forum 1(3): 70-80.

Bromilow, F. J.; Hinds, M. F.; Moody, N. F. 1980. AIQS survey on building contract time performance, The Building Economist 19(2): 79-82.

Car-Pušić, D. 2004. Metodologija planiranja održivog vremena gradenja [Methodology of planning the sustainable construction time]: PhD thesis. Građevinski fakultet Sveučilišta u Zagrebu [Faculty of Civil Engineering, University of Zagreb], Zagreb, Croatia. (in Croatian).

Car-Pušić, D.; Radujković, M. 2009. Construction time-cost model in Croatia, International Journal for Engineering Modelling 22(1-4): 63-70. 
Chan, D. W. M.; Kumaraswamy, M. M. 1995. A study of the factors affecting construction duration in Hong Kong, Construction Management and Economics 13(4): 319-333. http://dx.doi.org/10.1080/01446199500000037

Chan, D. W. M.; Kumaraswamy, M. M. 1999. Modelling and predicting construction durations in Hong Kong public housing, Construction Management and Economics 17(3): 351-362. http://dx.doi.org/10.1080/014461999371556

Chan, A. P. C. 2001. Time-cost relationship of public sector projects in Malaysia, International Journal of Project Management 19(4): 223-229. http://dx.doi.org/10.1016/S0263-7863(99)00072-1

Choudhury, I.; Rajan, S. S. 2003. Time-cost relationship for residential construction in Texas, Construction Informatics Digital Library [online], [cited 18 April 2014]. Available from Internet: http://itc. scix.net/data/works/att/w78-2003-73.content.pdf

Durson O.; Stoy, C. 2011. Time-cost relationship of building projects: statistical adequacy of categorization with respect to project location, Construction Management and Economics 29(1): 97-106. http://dx.doi.org/10.1080/01446193.2010.528437

Federalni zavod za statistiku [Federal Office of Statistics]. 2012. Mjesečni statistički pregled Federacije Bosne I Hercegovine [Monthly Statistical Review of the Federation of Bosnia and Herzegovina] 12, Sarajevo.

Flyvbjerg, B.; Skamris Holm, M.; Buhl, S. 2002. Underestimating costs in public works projects error or lie?, APA Journal 68(3): 279-295.

Hoffman, G. J.; Thal, A. E. Jr.; Webb, T. S.; Weir, J. D. 2007. Estimating performance time for construction projects, Journal of Management in Engineering 23(4): 193-199. http://dx.doi.org/10.1061/(ASCE)0742-597X(2007)23:4(193)

$\mathrm{Hu}, \mathrm{W}$; He, X. 2014. An innovative time-cost-quality tradeoff modeling of building construction project based on resource allocation, The Scientific World Journal. 10 p. Article ID 673248. http://dx.doi.org/10.1155/2014/673248

Ireland, V. 1983. The role of managerial actions in the cost, time and quality performance of high rise commercial building projects: PhD thesis. University of Sidney, Sidney, NSW.

Johnson, A.; Bhattacharyya, G. K. 2001. Statistics: principles and methods. University of Wisconsin at Madison.

Kaka, A.; Price, A. D. F. 1991. Relationship between value and duration of construction projects, Construction Management and Economics 9(4): 383-400. http://dx.doi.org/10.1080/01446199100000030

Kenny, C. 2010. Publishing construction contracts and outcome details. Policy Research Working Paper 5247. The World Bank Sustainable Development Department Finance, Economics and Urban Division. Available from Internet: http://elibrary.worldbank.org/doi/pdf/10.1596/1813-9450-5247

Khosrowshahi, F; Kaka, A. P. 1996. Estimation of project total cost and duration for housing projects in UK, Building and Environment 31(4): 373-383. http://dx.doi.org/10.1016/0360-1323(96)00003-0

Kumaraswamy, M. M.; Chan, D. W. M. 1995. Determinants of construction duration, Construction Management and Economics 13(3): 209-217. http://dx.doi.org/10.1080/01446199500000025

Le-Hoai, L.; Lee, Y. D.; Lee, J. Y. 2008. Delay and cost overruns in Vietnam large construction projects: a comparison with other selected countries, Journal of Civil Engineering 12(6): 367-377. http://dx.doi.org/10.1007/s12205-008-0367-7

Le-Hoai, L.; Lee, Y. D. 2009. Time-cost relationships of building construction project in Korea, Facilities 27(13/14): 549-559. http://dx.doi.org/10.1108/02632770910996379

Love, P. E. D.; Tse, R. Y. C.; Edwards, D. J. 2005. Time-cost relationship in Australian building construction projects, ASCE Journal of Construction Engineering and Management 138(5): 585-593. http://dx.doi.org/10.1061/(asce)0733-9364(2005)131:2(187)

Nikić, R. 1998. Upravljanje rizicima kod građevinskih projekata zemlje u tranziciji, [Construction project risk management in a transition country]: master's thesis. Građevinski fakultet, Sveučilište u Zagrebu, Faculty of Civil Engineering, University of Zagreb. (in Croatian). 
Nkado, N. R. 1992. Construction time information system for the building industry, Construction Management and Economics 10(6): 489-509. http://dx.doi.org/10.1080/01446199200000048

Olawale, Y. A.; Sun, M. 2010. Cost and time control of construction projects: inhibiting factors and mitigating measures in practice, Construction Management and Economics 28(5): 509-526. http://dx.doi.org/10.1080/01446191003674519

Pauše, Ž. 1993. Uvod u matematičku statistiku [Introduction to mathematical statistics]. Zagreb: Školska knjiga. (in Croatian).

Pavlić, I. 1988. Statistička teorija i primjena [Statistical theory and application]. Zagreb: Tehnička knjiga. (in Croatian).

Radujković, M. 1997. Upravljanje rizikom kod građevinskih projekata [Risk management in construction projects], Gradevinar 49(5): 247-255. (in Croatian).

Radujković, M. 1999. Upravljanje rizikom i resursima kod građevinskih projekata, znanstveno istraživački projekt MZITRH (Ministarstvo znanosti i tehnologije Republike Hrvatske) [Construction project risk and resource management, scientific research work of MST (Ministry of Science and Technology)], Građevinski fakultet, Sveučilište u Zagrebu, Faculty of Civil Engineering, University of Zagreb. (in Croatian).

Skitmor, R. M.; Ng, S. T. 2001. Australian project time-cost analysis: statistical analysis of intertemporal trends, Construction Management and Economics 19(5): 455-458.

Sun, C.; Xu, J. 2011. Estimation of time for Wenchuan Earthquake reconstruction in China, Journal of Construction Engineering and Management 137(3): 179-187. http://dx.doi.org/10.1061/(ASCE)CO.1943-7862.0000277

Žujo, V.; Car-Pušić, D. 2008. Application of "Time-Cost" model in construction project management, in Proc. of the $8^{\text {th }}$ International Conference on Organization, Technology and Management in Construction, 17-20 September 2008, Umag, Croatia.

Žujo, V. 2008a. Doprinos upravljanju građevinskim projektima kroz planiranje vremena [Contribution of construction time planning to construction project management]: $\mathrm{PhD}$ thesis. Građevinski fakultet, Univerzitet "Džemal Bijedić" in Mostar, Faculty of Civil Engineering, University "Džemal Bijedić" of Mostar. građenja. (in Bosnian).

Žujo, V. 2008b. Planiranje vremena građenja [construction time determination], in Proc. of the International Scientific Symposium "Construction - Science and Practice" GNP2008, 3-7 March 2008, Žabljak, 1325-1330 (in Bosnian).

Žujo, V.; Car-Pušić, D. 2009a. Prekoračenje ugovorenog roka građenja kao funkcija rizičnih faktora [Construction time overrun as a risk factor function], Gradevinar 61(8): 721-729. (in Croatian).

Žujo, V.; Car-Pušić, D. 2009b. Modeling of risk factor influence on construction time overrun by applying multivariate regression analysis, in CIB Joint International Symposium 2009, 27-30 September 2009, Dubrovnik, 148-157.

Žujo, V.; Car-Pušić, D.; Brkan-Vejzović, A. 2009a. Brza prognoza vremena građenja objekata niskogradnje [Rapid prognosis of construction time for civil engineering structures], INDIS 2009, 25-27 November 2009, Novi Sad, Serbia, 511-518.

Žujo, V.; Car-Pušić, D.; Brkan-Vejzović, A. 2009b. Utjecaj predračunske cijene na upravljanje izgradnjom cesta [Influence of the estimated cost on road construction management], II International BiH Congress on Roads, 24-25 September 2009, Sarajevo, Bosnia i Hercegovina (in Bosnian).

Žujo, V.; Car-Pušić, D.; Brkan-Vejzović, A. 2009c. Preliminarno planiranje izgradnje benzinskih pumpi, [Preliminary planning for petrol station construction], Transport and Transportation Infrastructure 9: 32-37. (in Bosnian).

Žujo, V.; Car-Pušić, D.; Brkan-Vejzović, A. 2010. Contracted price overrun as contracted construction time overrun function, Technical Gazette 17: 23-29. 
Vahida ŽUJO. PhD, Civ. Eng., works at the Faculty of civil Engineering, University of Mostar, Bosnia and Herzegovina. She is Associate Professor at the Department of Construction Organization and Technology. Before being an academic, she worked for several contractors in building industry. She has published 24 papers at international conferences, 2 papers at domestic journals and 6 papers at international journals on the subject of construction organization and technology. Also, she published a book entitled "Introduction to construction regulations". As a project leader she participated in 7 international scientific - research projects. She has lectured in Bosnia and Herzegovina and abroad. Research interests include time planning, construction economics, project management.

Diana CAR-PUŠIĆ. Prof., PhD, Professor for the subjects Construction Organization and Technology and Construction Economics. Head of the Department of Construction Organization, Technology and Architecture at the Faculty of Civil Engineering in Rijeka, Croatia. The author of approx. 40 articles on the subject of construction organization and technology took part in many scientific and professional conventions. The tutor and advisor to students at graduate and postgraduate studies. From 1985 till 1998 a researcher at the Institute of Civil Engineering. Research interests include time planning, construction equipment usage problems, especially the mechanization performance, construction procurement, especially constructability concept.

Valentina ŽILESKA-PANČOVSKA. PhD, Civ. Eng., is in charge for the Research in Construction management at the Faculty of Civil Engineering, University "Ss. Cyril and Methodius" in Skopje, Macedonia where she works as full professor. Before becoming an academic, she worked for a construction company. She has lectured and published in the Macedonia and abroad. She published more than 100 papers in domestic and international conferences and journals. She is the Chair of Technology and Organization of Construction at the Faculty of Civil Engineering in Skopje.

Marko ĆEĆEZ. MSc. Civ. Eng., works at the Faculty of Civil Engineering, University of Mostar, Bosnia and Herzegovina. He is assistant in department of Construction Organization and Technology. He conducts classes related to the construction organization, mechanization performance and construction management. As the author or co-author he has published 15 papers at international conferences and 1 paper at international journal. He participated as team member in 5 international scientific - research projects. Research interests include time planning, project management, concrete technologies, sustainable construction. 